\title{
Effects of a Partially Perforated Flooring System on Ammonia Emissions in Broiler Housing-Conflict of Objectives between Animal Welfare and Environment?
}

\author{
Carolin Adler ${ }^{1, *}$, Alexander J. Schmithausen ${ }^{2}$, Manfred Trimborn ${ }^{1} \oplus$, Sophia Heitmann ${ }^{3}$, Birgit Spindler ${ }^{3}{ }^{1}$,

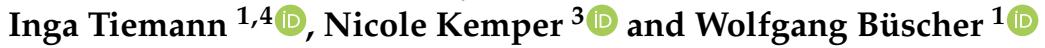

1 Institute of Agricultural Engineering, University of Bonn, 53115 Bonn, Germany; m.trimborn@uni-bonn.de (M.T.); inga.tiemann@uni-bonn.de (I.T.); buescher@uni-bonn.de (W.B.)

2 Corteva Agriscience, Riedenburger Straße 7, 81677 München, Germany; alexander.schmithausen@corteva.com

3 Institute of Animal Hygiene, Animal Welfare and Farm Animal Behaviour, University of Veterinary Medicine Hannover, Foundation, 30559 Hannover, Germany; sophia.heitmann@tiho-hannover.de (S.H.); birgit.spindler@tiho-hannover.de (B.S.); nicole.kemper@tiho-hannover.de (N.K.)

4 Institute of Animal Science, University of Bonn, 53115 Bonn, Germany

* Correspondence: c.adler@uni-bonn.de

check for updates

Citation: Adler, C.; Schmithausen, A.J.; Trimborn, M.; Heitmann, S.; Spindler, B.; Tiemann, I.; Kemper, N.; Büscher, W. Effects of a Partially Perforated Flooring System on Ammonia Emissions in Broiler Housing-Conflict of Objectives between Animal Welfare and Environment?. Animals 2021, 11, 707. https://doi.org/10.3390/ani 11030707

Academic Editors: Yang Zhao and Lilong Chai

Received: 11 February 2021

Accepted: 1 March 2021

Published: 5 March 2021

Publisher's Note: MDPI stays neutral with regard to jurisdictional claims in published maps and institutional affiliations.

Copyright: () 2021 by the authors. Licensee MDPI, Basel, Switzerland. This article is an open access article distributed under the terms and conditions of the Creative Commons Attribution (CC BY) license (https:// creativecommons.org/licenses/by/ $4.0 /)$.
Simple Summary: Previous studies have shown positive effects of a partially perforated flooring system on animal welfare in broiler housing. Towards the end of the fattening periods, the present study showed a higher ammonia emission rate $\left(\mathrm{NH}_{3} \mathrm{ER}\right)$ for a partially perforated flooring system compared with a littered control barn. Nevertheless, the measured $\mathrm{NH}_{3}$ concentrations were below 20 ppm, except during a mechanical litter treatment in the winter fattening period. Furthermore, the system offers the possibility of applying practical solutions that were not feasible before. By using underfloor air extraction, manure belts, or acidification systems underneath the elevated perforated area, $\mathrm{NH}_{3}$ concentrations and the resulting $\mathrm{NH}_{3}$ ER could be reduced. Thus, with some optimization, the partially perforated flooring system could be used to contribute to an increase in animal welfare and environmental protection at the same time.

Abstract: A partially (50\%) perforated flooring system showed positive effects on health- and behavior-based welfare indicators without affecting production performance. Ammonia $\left(\mathrm{NH}_{3}\right)$ is the most common air pollutant in poultry production, with effects on animal welfare and the environment. The objectives of animal welfare and environmental protection are often incompatible. Therefore, this study addresses the question of how a partially perforated flooring system affects $\mathrm{NH}_{3}$ emissions. According to German regulations, three fattening periods were carried out with 500 Ross 308 broilers per barn (final stocking density: $39 \mathrm{~kg} \mathrm{~m}^{-2}$ ). The experimental barn was equipped with an elevated perforated area in the supply section, accessible by perforated ramps. The remaining area in the experimental barn and the control barn were equipped with wood shavings $\left(600 \mathrm{~g} \mathrm{~m}^{-2}\right)$. Besides the different floor types, management was identical. Air temperature (Temp), relative air humidity $(\mathrm{RH}), \mathrm{NH}_{3}$ concentration, and ventilation rate (VR) were measured continuously. Furthermore, dry matter (DM) content, $\mathrm{pH}$, and litter quality were assessed. Towards the end of the fattening periods, the $\mathrm{NH}_{3}$ emission rate (ER) of the partially perforated flooring system was higher compared with that of the littered control barn (all $p<0.001$ ). This effect is mainly caused by the higher $\mathrm{NH}_{3}$ concentrations, which are promoted by the lack of compaction underneath the elevated perforated area and the increase in $\mathrm{pH}$ value under aerobic conditions. Nevertheless, the partially perforated flooring system offers different approaches for $\mathrm{NH}_{3}$ reduction that were previously not feasible, potentially contributing equally to animal welfare and environmental protection.

Keywords: broiler production; alternative flooring; ammonia emissions; animal welfare; environmental impact 


\section{Introduction}

In Germany, broilers are conventionally kept on concrete floors equipped with organic bedding materials [1]. From day 14, about $80 \%$ of the litter's dry matter (DM) consists of excrements and feed residues [2]. If the drying conditions are unfavorable, footpad dermatitis, hock burn, and plumage contamination occur [3-5]. As the abovementioned aspects lead to pain and secondary diseases, the incidence and severity are used as animalbased indicators to record animal welfare [6-8]. In addition, the litter provides a potential reservoir for antibiotic-resistant bacteria [9] that can be transmitted to humans via the food chain $[10,11]$. Two studies were carried out in the past comparing an innovative partially $(50 \%)$ perforated flooring system with a littered flooring system [12,13]. One feature of the partially perforated flooring system is an elevated perforated area in the section of feed and water supply, accessible by perforated ramps. Next to the elevated perforated area, littered areas are available. The system provides access to two different floor types at different height levels and promotes the animals' natural behavior such as perching and resting on elevated levels $[14,15]$ or pecking, scratching, and dustbathing in contact with litter $[16,17]$. At the same time, animals are separated from at least $50 \%$ of the litter, which contains excrements, moisture, and bacteria. Adler et al. [12] examined the effect of the partially perforated flooring system on animal-based welfare indicators and production performance. The creation of different functional areas at different heights enriched the husbandry environment, increased the environmental complexity, and reduced animals' general fear response, as confirmed by $[18,19]$. Furthermore, the separation of the animals from at least $50 \%$ of the litter had a positive influence on foot pad dermatitis and hock burn. Production performance was not affected by the floor type [12]. Heitmann et al. [13] studied the effect of the partially perforated flooring system on the occurrence of bacteria. A tendency was shown for a higher content of Escherichia coli (E. coli) in the supply area of the partially perforated system compared with the supply area of the littered flooring system. Owing to the elevated perforated area, the animals did not come into contact with the material containing E. coli underneath the perforated floor. Regarding the total bacteria count, a tendency for lower contents in the littered side areas of the partially perforated flooring system was found compared with the littered control barn. In summary, the partially perforated flooring system has a positive effect on health- and behavior-based welfare indicators without a reduction in production performance [12].

Due to the conflict of objectives between animal welfare and the environment, it is also important to consider the influence of the partially perforated flooring system on environmental aspects [20]. Ammonia $\left(\mathrm{NH}_{3}\right)$ is the most common air pollutant emitted by poultry production [21]. Several studies revealed that $\mathrm{NH}_{3}$ has negative effects on human and animal health as well as the environment. $\mathrm{NH}_{3}$ inside the barn is known to irritate the mucous membranes and damage the respiratory tract of humans and animals [22-24]. Negative effects on broilers' production performance as a result of $\mathrm{NH}_{3}$ concentrations above $30 \mathrm{ppm}$ were also observed [25,26]. Furthermore, $\mathrm{NH}_{3}$ released in the air from poultry houses is able to contribute to the production of acid rain [27] and therefore nitrogen $(\mathrm{N})$ deposition in the ecosystem [28]. Potential consequences of $\mathrm{N}$ deposition are eutrophication, acidification, less biodiversity, and nitrification of groundwater [29].

Several studies have been carried out on different flooring systems with regard to $\mathrm{NH}_{3}$. For example, Boggia et al. [30] showed a reduction in the $\mathrm{NH}_{3}$ concentration using a no-litter flooring system for broilers compared with conventional litter flooring. Almeida et al. [31] used a totally (100\%) perforated flooring system and showed a reduction in the $\mathrm{NH}_{3}$ concentration, if manure was continuously removed during the fattening period. In the case of manure storage underneath a totally $(100 \%)$ perforated flooring system over several fattening periods, the $\mathrm{NH}_{3}$ concentrations and the resulting $\mathrm{NH}_{3}$ emissions were higher compared with litter flooring [32].

It is known that the partially perforated flooring system has positive effects on animalbased welfare indicators [12]. So far it is not known how the partially perforated flooring system affects $\mathrm{NH}_{3}$ emissions and whether harmful $\mathrm{NH}_{3}$ concentrations are to be expected. 
Therefore, the aim of this study was to investigate the effect of the partially perforated flooring system on $\mathrm{NH}_{3}$ emissions compared with a littered system.

\section{Materials and Methods}

\subsection{Animals and Housing}

This case-control study was carried out at the Educational and Research Center Frankenforst of the Faculty of Agriculture, University of Bonn (Königswinter, Germany; $55^{\circ} 42^{\prime} 55 \mathrm{~N}$ and $7^{\circ} 12^{\prime} 26 \mathrm{E}$ ). The experiments were performed in accordance with German regulations and approved by the relevant authority (Landesamt für Natur-, Umwelt- und Verbraucherschutz Nordrhein-Westfalen, Recklinghausen; 81.02.04.2018.A057). A total of three fattening periods were carried out in three different seasons from August 2018 to June 2019. Due to specifications of the slaughterhouse, each fattening period lasted 31 to 32 days. The study was carried out according to German regulations by housing 500 Ross 308 broilers per barn and fattening period to achieve a final stocking density of $39 \mathrm{~kg} \mathrm{~m}^{-2}$. Two identical barns were used to fulfill the conditions of a case-control study (experimental vs. control barn). Both barns were automatically ventilated by negative pressure ventilation, regulated identically via climate computers (PL-9400, Stienen Bedrijfselektronica B.V., RT Nederweert, The Netherlands). More information on management, feeding, lighting program, and vaccination can be found in the previous study by Adler et al. [12].

\subsection{Floor Design and Litter Management}

Figure 1 illustrates the two different flooring systems. The experimental barn was equipped with an elevated perforated floor in the area of feed and water supply, accessible by perforated ramps. Conventional wood shavings $\left(600 \mathrm{~g} \mathrm{~m}^{-2}\right)$ were used in the concrete floor areas next to the feed and water supply. The control barn was completely equipped with wood shavings $\left(600 \mathrm{~g} \mathrm{~m}^{-2}\right)$.

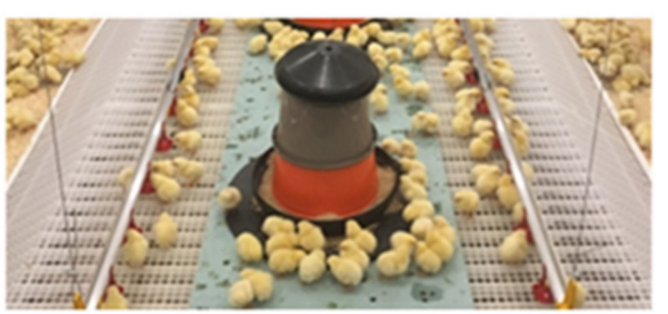

Partially perforated

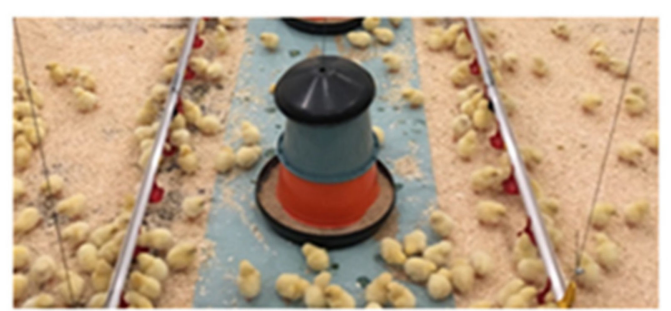

Littered

Figure 1. Illustration of the partially perforated flooring system, with an elevated perforated area in the section of feed and water supply, and the littered flooring system.

After each fattening period, both barns were cleaned, disinfected, and provided with new wood shavings. During the winter fattening period, the litter was additionally mechanically treated with a rake on day 11 to ensure an even distribution in all areas of the barn, especially in the area near the ramps.

\subsection{Indoor Environmental Factors}

Inside the barn, air temperature (Temp) and relative air humidity $(\mathrm{RH})$ were measured every three minutes using data loggers (Tinytag Plus 2-TGP-4500 loggers, Gemini Data Loggers Ltd., Chichester, West Sussex, UK). A total of three data loggers per barn were placed in the same positions and at a height of $55 \mathrm{~cm}$ (Figure 2). Data regarding Temp and $\mathrm{RH}$ in the environment outside the barns were provided every $10 \mathrm{~min}$ by the nearby weather station at a height of $2.0 \mathrm{~m}$ (Königswinter, Germany; $50^{\circ} 42^{\prime} 54 \mathrm{~N}$ and $7^{\circ} 12^{\prime} 31 \mathrm{E}$ ). 


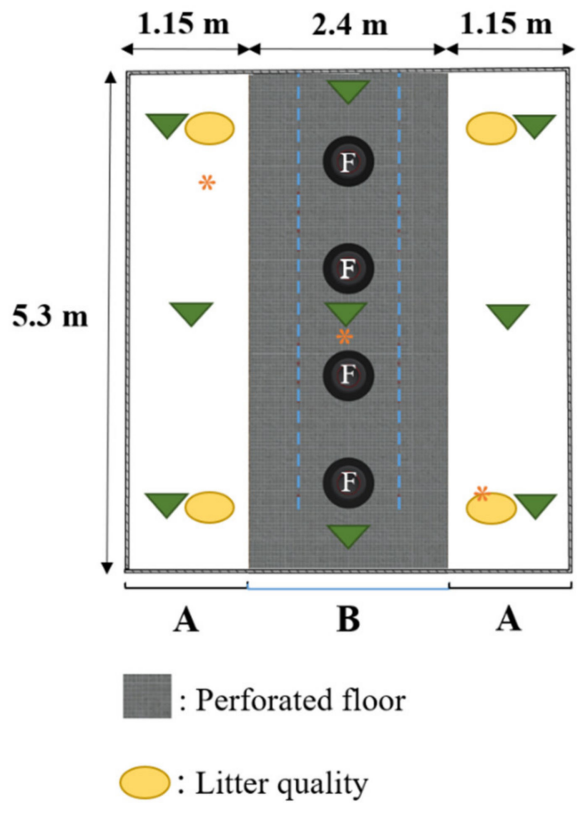

A : Littered side areas

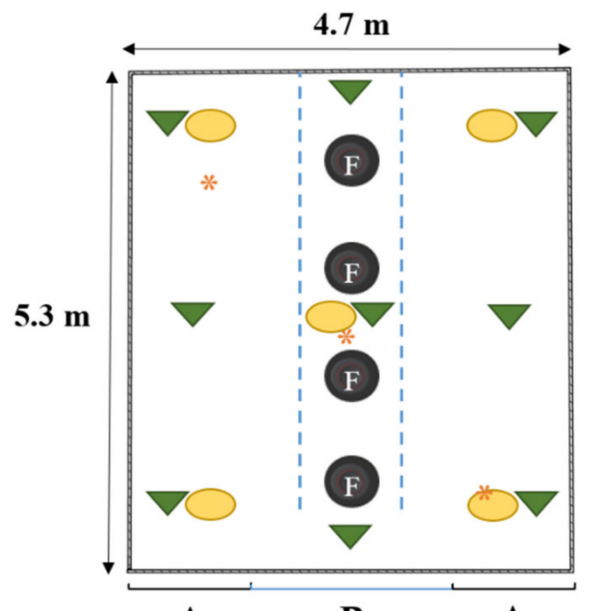

A

$\mathbf{A}$

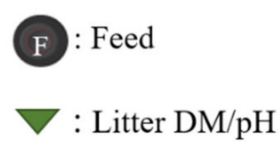

B : Supply area

Figure 2. Floor plan view of the partially perforated flooring system, with an elevated perforated area in the section of feed and water supply, and the littered flooring system, including measurement positions for litter quality, litter dry matter (DM), litter $\mathrm{pH}(\mathrm{pH})$, air temperature (Temp), and relative air humidity $(\mathrm{RH})$.

\subsection{Ammonia Concentration}

The $\mathrm{NH}_{3}$ concentrations were measured continuously via photoacoustic infrared spectroscopy using a Photoacoustic Gas Monitor INNOVA 1412 in combination with a Multipoint Sampler INNOVA 1309 (LumaSense Technologies SA, Ballerup, Dennmark). The measurement setup was based on studies carried out by Schmithausen et al. [33,34]. Additionally, the gas monitor was calibrated by the manufacturer and regularly checked in the measuring laboratory between the fattening periods. In total, three sampling points were installed with filter orifices to protect the technique from dust. Two sample points were installed in the exhaust chimneys of the barns. A third sampling point was installed outside the barns to measure the background concentration. The air of each sampling point was collected continuously by vacuum pumps (ME 2C, Vacuubrand GmbH + Co. KG, Wertheim, Germany) through polytetrafluoroethylene tubes in three separate sample bottles $(600 \mathrm{~mL})$. The tubes were equipped with heating cables (A. Rak Wärmetechnik $\mathrm{GmbH}$, Frankfurt am Main, Germany) to avoid water condensation in the tubes with temperature decrease. Due to the continuously flushed sample bottles and tube system, there was always actual sample air available. The tubes between the sample bottles and the Multipoint Sampler were as short as possible $(<0.5 \mathrm{~m})$. This measurement setup is useful to ensure a small distance from the sampling point until the analysis. One measuring cycle lasted three minutes with a measuring time of $60 \mathrm{~s}$ per sampling point.

\subsection{Ventilation Rate}

The ventilation rate (VR) in both exhaust chimneys was estimated using ProVent measurement fans (Reventa $\mathrm{GmbH}$, Horstmar, Germany) of the same diameter as the exhaust chimney. The measuring fans were calibrated in a wind tunnel by the manufacturer. There was a calming distance of $2.0 \mathrm{~m}$ between the air outlet and the measuring fan to fulfill laminar air flow conditions. These conditions are useful to increase the measurement accuracy of the measurement fans. The data were recorded every minute by Almemo 2590 data loggers (Ahlborn Mess- und Regelungstechnik GmbH, Holzkirchen, Germany). 


\subsection{Litter Analysis}

At the end of each fattening period on day 31 to 32, representative litter samples were taken to determine the litter dry matter (DM). In the spring fattening period, further litter samples were taken on days 7, 14,21, and 28. Litter samples were taken in nine different positions: a total of six positions in the littered side areas and three positions in the supply area of each barn (Figure 2). In each position, a sample of the entire depth of the litter was taken. The litter samples were weighed before and after being oven-dried at $105^{\circ} \mathrm{C}$ for $24 \mathrm{~h}$.

In addition, the litter samples of the spring fattening period were analyzed regarding the $\mathrm{pH}$ value. A total amount of $20 \mathrm{~g}$ of each litter sample was mixed with $300 \mathrm{~g}$ deionized water. The samples were then shaken with an overhead shaker (Reax 20 overhead shaker, Heidolph Instruments GmbH \& Co. KG, Schwabach, Germany) for a total time of one hour (30 turns $\mathrm{m}^{-1}$ ). After shaking, the $\mathrm{pH}$ was measured using a $\mathrm{pH}$ electrode (InLab Max Pro-ISM electrode, Mettler Toledo, OH, USA). The $\mathrm{pH}$ electrode was calibrated using a buffer solution for $\mathrm{pH} 4$ and 7 .

\subsection{Litter Quality}

In all three fattening periods, litter quality was assessed on days 7, 14, 21, and 28 using the scoring system developed by Welfare Quality ${ }^{\circledR}$ [35]. Figure 2 shows the positions where litter quality was evaluated. A total of five litter samples were taken in the littered control barn, with four samples in the littered side areas and one sample in the supply area. In the experimental barn, four litter samples were taken in the littered side areas. No litter quality assessment was performed underneath the perforated area in the supply area of the experimental barn. Underneath the perforated area, mainly excrements are stored, which cannot be defined and evaluated as litter. A scoring system from 0 to 4 was used to evaluate the litter quality [35]. Figure 3 illustrates the images of the different scores. Score 0 was equal to "completely dry and flaky, that is, moves easily with the foot"; score 1 was equal to "dry but not easy to move with foot"; score 2 was equal to "leaves imprint of foot and will form a ball if compacted, but ball does not stay together well"; score 3 was equal to "sticks to boots and sticks readily in a ball if compacted"; and score 4 was equal to "sticks to boots once the cap or compacted crust is broken."

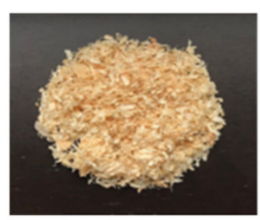

0

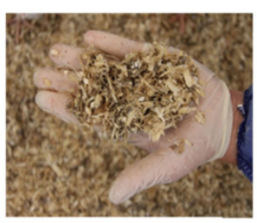

1

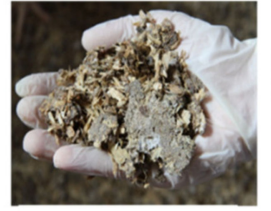

2

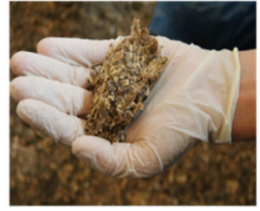

3

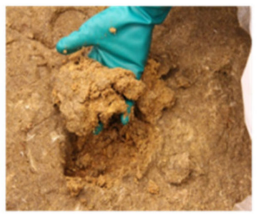

4

Figure 3. Illustration of the scores used during the litter quality evaluation.

\subsection{Data Processing and Statistical Analysis}

For statistical analysis, SPSS ${ }^{\circledR}$ Statistics 25 (IBM Corporation, Armonk, NY, USA) was used. Graphical presentation was done with SigmaPlot 14.0 (Systat Software Inc., Chicago, IL, USA). The daily emission rate (ER) was calculated using the average hourly $\mathrm{NH}_{3}$ concentrations ( $n=20$ values per hour and sample point) and the average hourly ventilation rates ( $n=60$ values per hour and barn) using the following equation:

$$
\mathrm{ER}=\left(\left(\left(\mathrm{C}_{\text {inside }}-\mathrm{C}_{\text {outside }}\right) \times \mathrm{VR}\right) / \mathrm{N}\right) \times 24
$$

where:

$\mathrm{ER}=$ emission rate $\left(\mathrm{g} \mathrm{d}^{-1}\right.$ bird $\left.^{-1}\right)$

$\mathrm{C}_{\text {inside }}=$ inside ammonia concentration $\left(\mathrm{g} \mathrm{m}^{-3}\right)$

$\mathrm{C}_{\text {outside }}=$ outside ammonia concentration $\left(\mathrm{g} \mathrm{m}^{-3}\right)$

$\mathrm{VR}=$ ventilation rate $\left(\mathrm{m}^{3} \mathrm{~h}^{-1}\right)$ 
$\mathrm{N}=$ actual number of birds per day

For each fattening period, the hourly values for $\mathrm{NH}_{3} \mathrm{ER}, \mathrm{NH}_{3}$ concentration, VR, air Temp, and $\mathrm{RH}$ were divided into three sections according to the feeding program: start (day 0 to 6), middle (day 7 to 27), and end of the fattening period (day 28 to 31 or 32). Data were analyzed using general linear models (GLMs). For litter quality, the link function was Poisson distributed, otherwise it was linear distributed. In the first step, univariate GLMs were used to select the significant main effects with $\mathrm{NH}_{3} \mathrm{ER}, \mathrm{NH}_{3}$ concentration, VR, air Temp, $\mathrm{RH}$, litter quality, $\mathrm{DM}$, and $\mathrm{pH}$ as response variables. Significant main effects were then analyzed by a multifactorial GLM. After backward selection, the final GLMs were interpreted with interaction terms (Fattening period $\times$ Section $\times$ Floor type, Area $\times$ Fattening period, or Area $\times$ Day). The $p$-values were corrected by Bonferroni. Differences of $p \leq 0.05$ were considered statistically significant, and differences of $0.05 \leq p \leq 0.10$ were considered a tendency.

\section{Results}

\subsection{Indoor Environmental Factors}

Figure 4 shows typical Temp curves with a decreasing Temp towards the end of the fattening periods (all $p<0.001$ ). During the summer fattening period, no additional heating sources were used. Therefore, the barn Temp of the summer fattening period was more oriented to the outside Temp. The initial Temp differences between both floor types in the summer fattening period are due to the settings of the climate computer $(p<0.01)$.

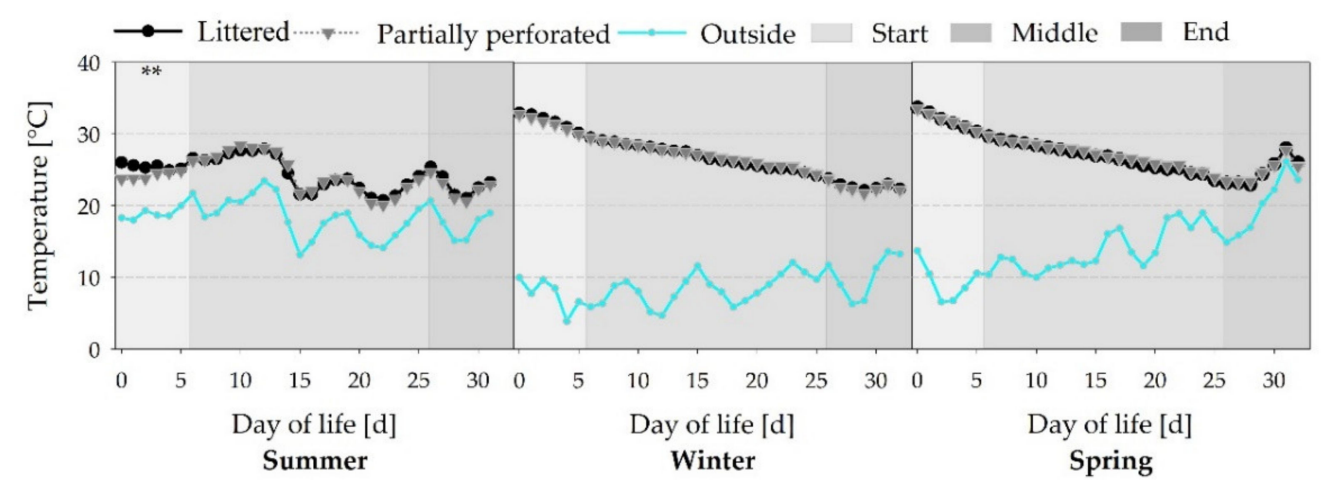

Figure 4. Average daily air temperature inside the broiler houses with two different floor types, and the outside environment air temperature measured over three different fattening periods $(n=144$ values per day and barn). Significant differences between both floor types within the three different sections (start, middle, end of the fattening period) are marked by asterisks: ${ }^{* *} p<0.01$.

An increase in $\mathrm{RH}$ from the start to the end of the three fattening periods is presented in Figure 5 (all $p<0.001$ ). Analogous to the Temp, the summer fattening period is oriented to the outside RH. Differences in RH between the flooring systems in the start and middle sections of the summer fattening period are due to the settings of the climate computer (all $p<0.05$ ). On day 11 of the winter fattening period, the litter was mechanically treated, resulting in an $\mathrm{RH}$ peak. At this time, the $\mathrm{RH}$ was higher for the littered control barn compared with the partially perforated flooring system $(p<0.001)$. 


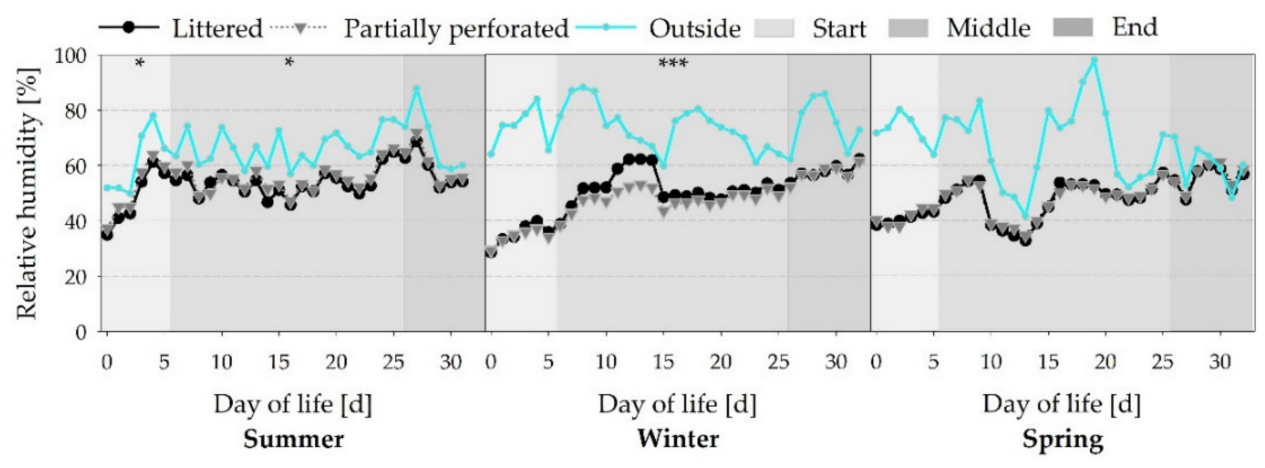

Figure 5. Average daily relative air humidity inside the broiler houses with two different floor types, and the outside environment RH measured over three different fattening periods $(n=144$ values per day and barn). Significant differences between both floor types within the three different sections (start, middle, end of the fattening period) are marked by asterisks: ${ }^{*} p \leq 0.05,{ }^{* * *} p<0.001$.

\subsection{Ammonia Concentration}

Figure 6 shows a typical increase in $\mathrm{NH}_{3}$ concentration towards the end of the fattening periods (all $p<0.01$ ). Higher ventilation rates in the summer fattening period reflect lower $\mathrm{NH}_{3}$ concentrations (all $p<0.001$ ). Owing to the mechanical litter treatment on day 11 of the winter fattening period, an $\mathrm{NH}_{3}$ concentration peak occurred. This peak was higher in the littered control barn than in the barn with the partially perforated flooring system $(p<0.001)$. Towards the end of the winter and spring fattening periods, $\mathrm{NH}_{3}$ concentrations of the partially perforated flooring system were higher compared with the littered control barn (all $p<0.01)$.

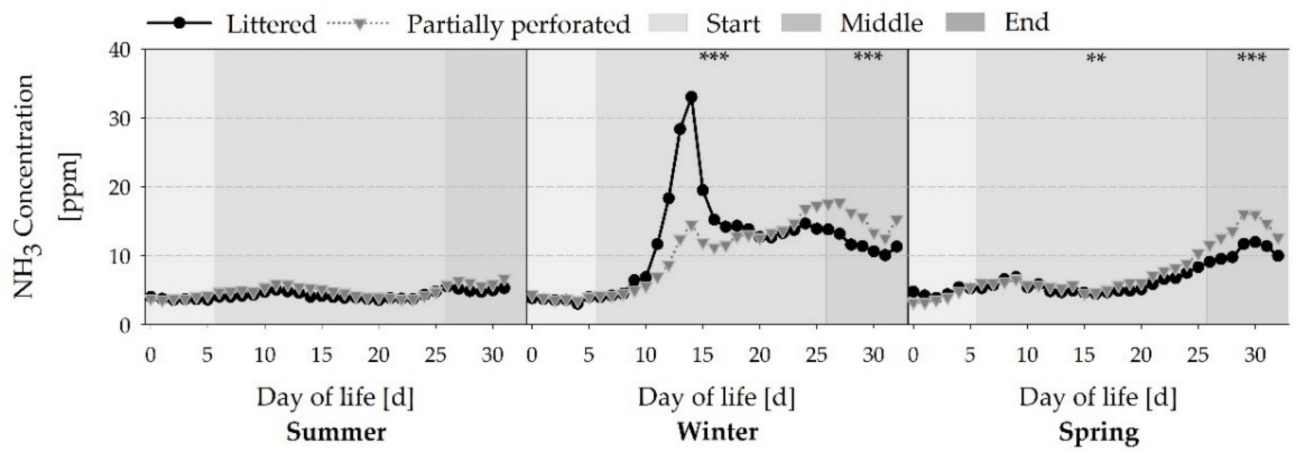

Figure 6. Average daily ammonia $\left(\mathrm{NH}_{3}\right)$ concentrations from broiler houses with two different floor types measured over three different fattening periods ( $n=480$ values per day and barn). Significant differences between both floor types within the three different sections (start, middle, end of the fattening period) are marked by asterisks: ${ }^{* *} p<0.01{ }^{* * *} p<0.001$.

\subsection{Ventilation Rate}

A typical course with an increasing VR towards the end of the fattening periods is shown in Figure 7 (all $p<0.001$ ). Depending on the seasons, the highest VR is shown in the summer compared with the winter and spring fattening periods (all $p<0.001)$. Differences between both floor types in the middle section of the summer fattening period are due to the settings of the climate computer $(p<0.001)$. The VR is a preset parameter of the climate computer, resulting in parallel VR curves. 


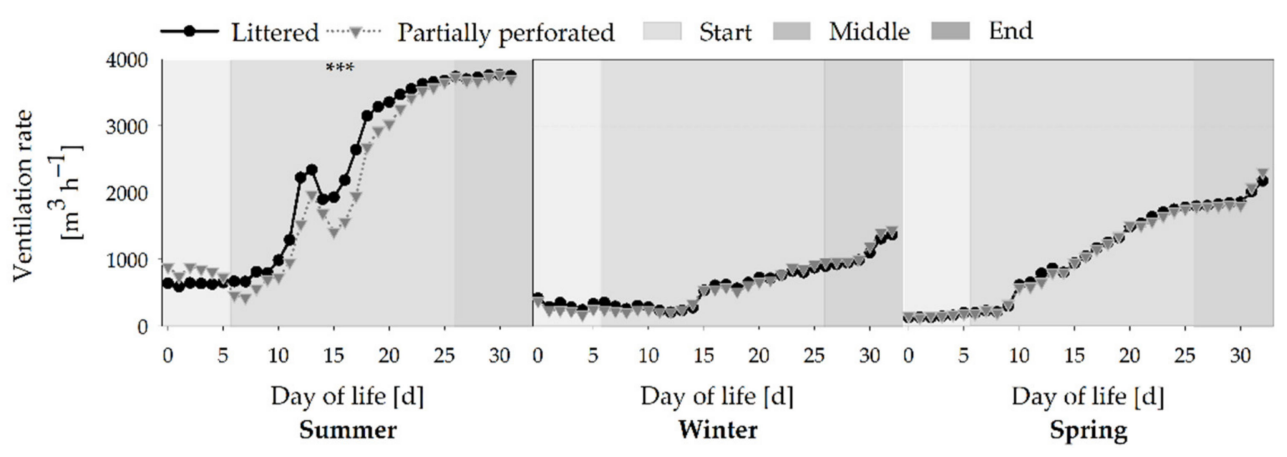

Figure 7. Average daily ventilation rate from broiler houses with two different floor types measured over three different fattening periods ( $n=1.440$ values per day and barn). Significant differences between both floor types within the three different sections (start, middle, end of the fattening period) are marked by asterisks: ${ }^{* * *} p<0.001$.

\subsection{Ammonia Emission Rate}

Figure 8 shows a common $\mathrm{NH}_{3}$ ER increase over the time for all fattening periods (all $p<0.001)$. Overall, the average $\mathrm{NH}_{3}$ ER of the three fattening periods was lower for the littered control barn $\left(0.15 \pm 0.12 \mathrm{~g} \mathrm{day}^{-1} \mathrm{bird}^{-1}\right)$ compared with the partially perforated flooring system $\left(0.19 \pm 0.19 \mathrm{~g}\right.$ day $\left.^{-1} \mathrm{bird}^{-1}\right)$. These differences were especially observed towards the end of the fattening periods, with a lower $\mathrm{NH}_{3}$ ER for the littered control barn than for the partially perforated flooring system (all $p<0.001$ ). Drifting apart of the $\mathrm{NH}_{3}$ ER between the two flooring systems began on days 26, 22, and 18 for the summer, winter, and spring fattening periods, respectively. Furthermore, a stagnation of the $\mathrm{NH}_{3}$ ER could be observed in the end section of the littered control barn in the summer and winter fattening periods.

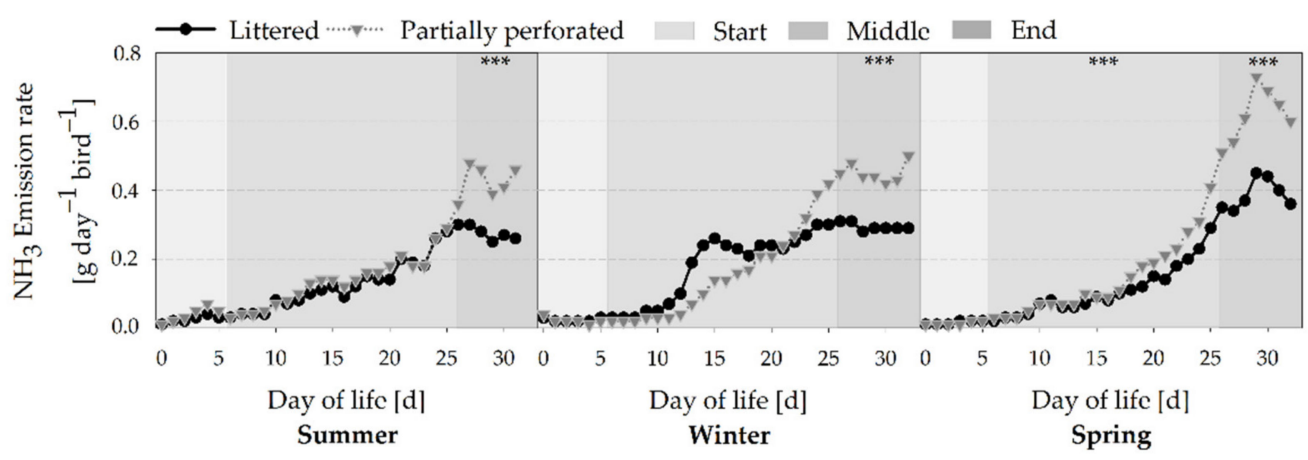

Figure 8. Average daily ammonia $\left(\mathrm{NH}_{3}\right)$ emission rate from broiler houses with two different floor types measured over three different fattening periods ( $n=24$ values per day and barn). Significant differences between both floor types within the three different sections (start, middle, end of the fattening period) are marked by asterisks: ${ }^{* *} p<0.001$.

\subsection{Litter Analysis}

The average litter DM at the end of the fattening periods is shown in Figure 9. At the end of the summer fattening period, litter DM was higher in the barn with the partially perforated flooring system compared with litter flooring $(p=0.004)$. In the supply area, litter DM was always lower for the partially perforated flooring system (all $p<0.032$ ). 


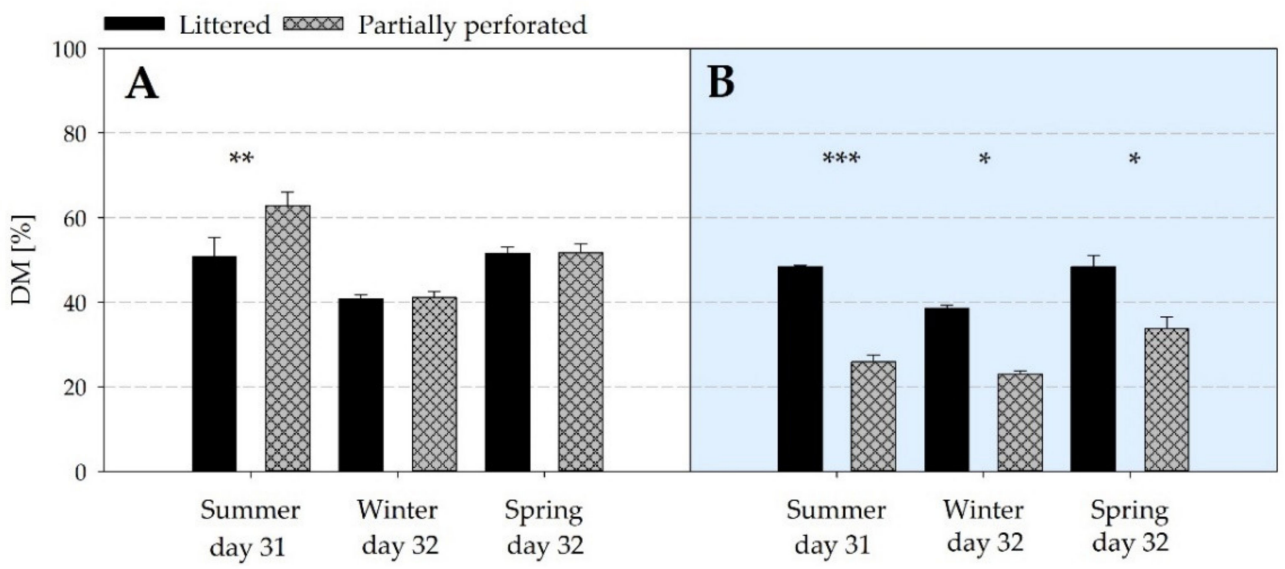

Figure 9. Average dry matter (DM) contents of litter samples from (A) the littered side areas and (B) the supply area from broiler houses with two different floor types at the end of each of the three different fattening periods ( $n=6$ values per fattening period and barn in area (A); $n=3$ values per fattening period and barn in area (B)). Significant differences are marked by asterisks: ${ }^{*} p \leq 0.05$, ** $p<0.01,{ }^{* * *} p<0.001$.

The effect of a lower litter DM in the supply area of the experimental barn compared with the control barn is also reflected in Figure 10 over the whole spring fattening period (all $p \leq 0.01$ ).

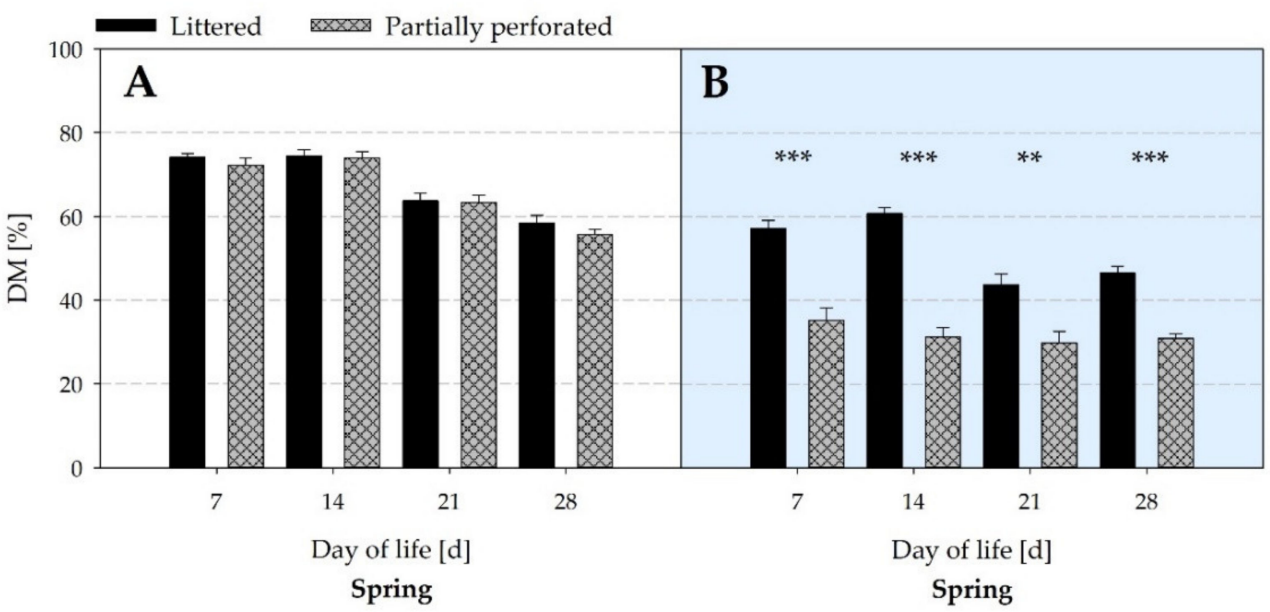

Figure 10. Average dry matter (DM) contents of litter samples from (A) the littered side areas and (B) the supply area ( $n=6$ values per day and barn in area (A); $n=3$ values per day and barn in area (B)) from broiler houses with two different floor types measured over the spring fattening period. Significant differences are marked by asterisks: ${ }^{* *} p<0.01,{ }^{* * *} p<0.001$.

Figure 11 presents the average daily litter $\mathrm{pH}$ values of the spring fattening period. In the littered side areas, litter $\mathrm{pH}$ increased from day 1 to 32 for both floor types (all $p<0.001$ ). On day 21, litter $\mathrm{pH}$ in the littered side areas was higher in the control barn compared with the partially perforated flooring system $(p=0.032)$. In the supply area of the control barn, litter $\mathrm{pH}$ increased from day 14 to 28 and dropped back to the starting level by day 32 (all $p<0.015$ ). By contrast, there was a continuous increase in litter $\mathrm{pH}$ from day 14 in the supply area of the barn with the partially perforated flooring system (all $p<0.001$ ). From day 28 , litter $\mathrm{pH}$ in the supply area was higher in the barn with the partially perforated flooring system compared with litter flooring (all $p<0.015)$. 


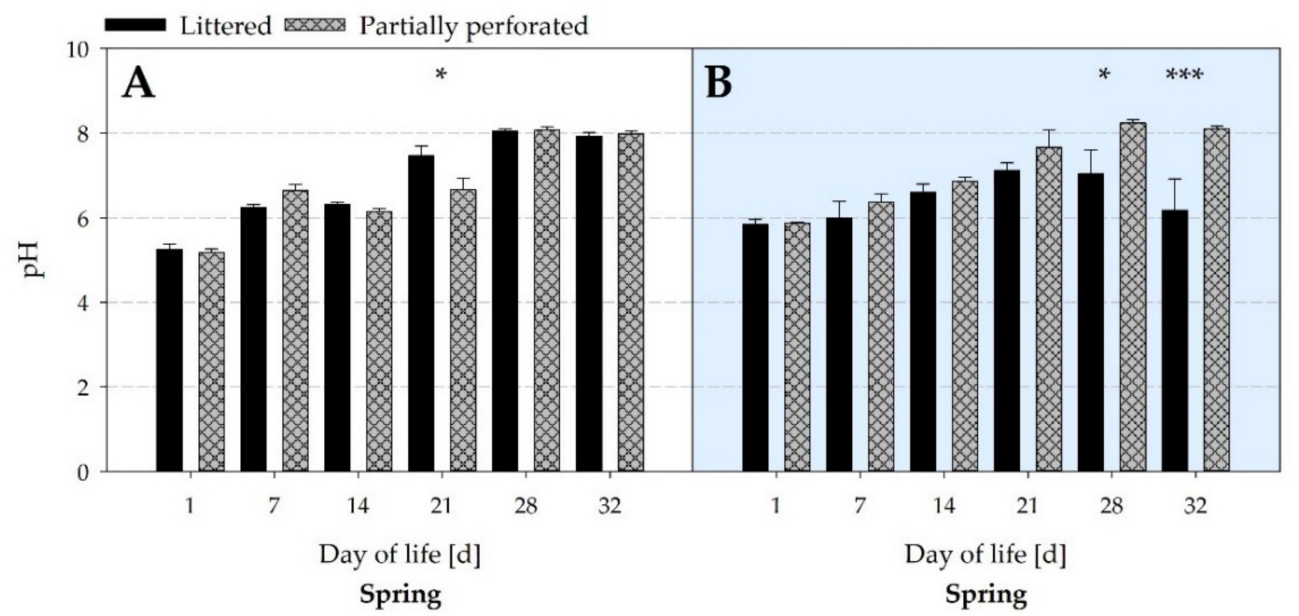

Figure 11. Average $\mathrm{pH}$ values of litter samples from (A) the littered side areas and (B) the supply area from broiler houses with two different floor types measured over the spring fattening period ( $n=6$ values per day and barn in area (A); $n=3$ values per day and barn in area (B)). Significant differences are marked by asterisks: ${ }^{*} p \leq 0.05,{ }^{* * *} p<0.001$.

\subsection{Litter Quality}

Figure 12 presents a decrease in the litter quality of the littered side areas from the start to the end of the fattening periods $(p<0.001)$. For the littered control barn, litter quality was higher in the littered side areas compared with the supply area $(p=0.002)$. In the supply area of the littered control barn, the highest litter quality score was achieved from day 14 with a fully compacted litter surface. This score was never found in the littered side areas for both floor types. No litter quality assessment was carried out in the supply area of the experimental barn, as the accumulated excrements underneath the perforated area cannot be scored as litter.

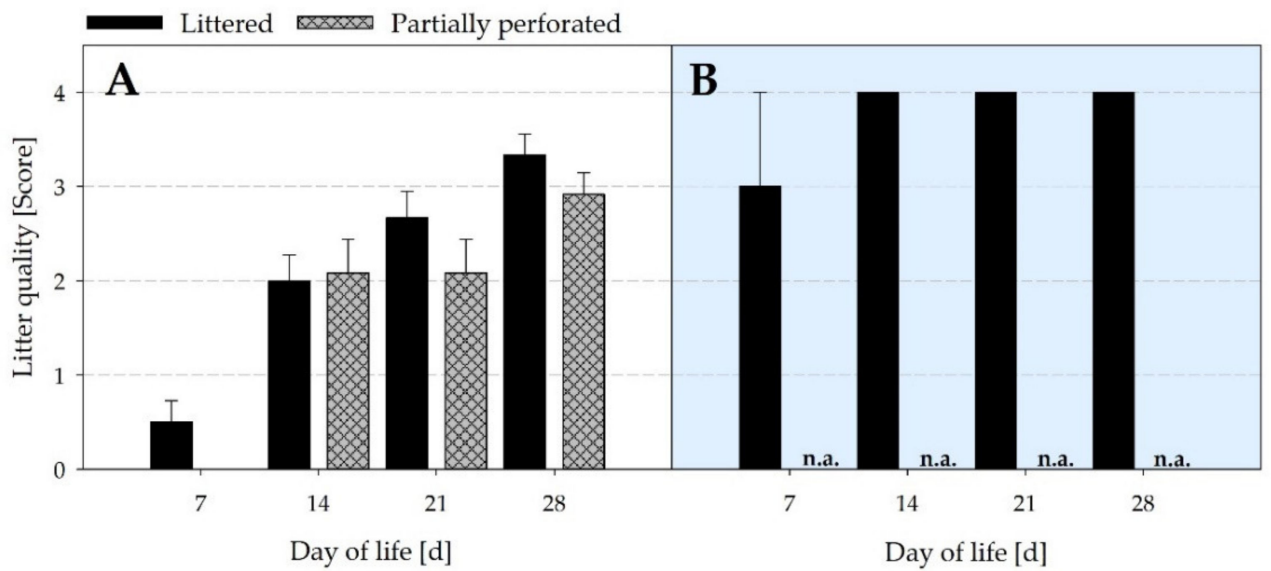

Figure 12. Mean scores of litter quality from (A) the littered side areas $(n=12$ values per day and barn) and (B) the supply area ( $n=3$ values per day and barn) from broiler houses with two different floor types. n.a. = not assessed (no litter quality assessment underneath the perforated area in the supply area of the experimental barn).

\section{Discussion}

A multifactorial evaluation of an innovative flooring system in broiler production is important to ensure the compatibility of animal welfare and the environment. Previous studies have shown positive effects of a partially perforated flooring system on animalbased welfare indicators, without affecting production performance or the occurrence of bacteria $[12,13]$. Positive effects of elevated perforated areas on health- and behavior- 
based welfare indicators are confirmed by numerous studies [18,19,36-39]. Conflicting information is available regarding the environmental impact of a totally perforated flooring system, with a focus on $\mathrm{NH}_{3}$ concentration and ER [31,32]. No results are published on the effect of a partially perforated flooring system on $\mathrm{NH}_{3}$ concentration and ER.

By measuring the $\mathrm{NH}_{3}$ concentrations and VR, the $\mathrm{NH}_{3} \mathrm{ER}$ was calculated. Results showed that the $\mathrm{NH}_{3}$ ER of the partially perforated flooring system was higher compared with the littered control barn towards the end of the fattening periods. Since no differences occurred in the VR between both flooring systems at that time, the higher $\mathrm{NH}_{3} \mathrm{ER}$ is explained by the higher $\mathrm{NH}_{3}$ concentrations. As reported by Groot Koerkamp [40], $\mathrm{NH}_{3}$ is mainly generated from the decomposition of uric acid and undigested protein excreted by the broilers. $\mathrm{NH}_{3}$ volatilization depends on several factors such as VR, indoor Temp, and $\mathrm{RH}$, as well as litter characteristics such as $\mathrm{DM}$ and $\mathrm{pH}$ [41]. In the current study, no differences in Temp and RH were measured towards the end of the fattening periods. Litter DM in the supply area was higher in the control compared with the experimental barn. From day 28, the $\mathrm{pH}$ in the supply area of the control barn was in an acidic range, and in the supply area of the experimental barn the $\mathrm{pH}$ was in an alkaline range. In addition, litter quality assessment revealed cake formation in the supply area of the control barn from day 14 .

A decrease in litter DM increases the $\mathrm{NH}_{3}$ volatilization [42]. Groot Koerkamp [40] reported that $40-60 \%$ litter DM provides the best conditions for microbial growth and thus for the release of $\mathrm{NH}_{3}$. Therefore, Miles et al. [43] stated that $54-55 \%$ of the total $\mathrm{NH}_{3}$ generated by the litter can be expected near the water lines promoted by the low litter DM level. The dissociation equilibrium between ammonium $\left(\mathrm{NH}_{4}{ }^{+}\right)$and $\mathrm{NH}_{3}$ is strongly $\mathrm{pH}$-dependent. With an increase in the litter $\mathrm{pH}$ above $\mathrm{pH} 7, \mathrm{~N}$ is increasingly released as $\mathrm{NH}_{3}$ due to the microbial implementation processes [44-47]. This is supported by a function set up by Kirchmann and Lundvall [48], explaining 79\% of the variance in the extent of the $\mathrm{NH}_{3}$ volatilization from animal wastes due to an increase in $\mathrm{pH}$ value. Various studies on the storage of animal excrements showed that the $\mathrm{NH}_{3}$ release is promoted by aerobic conditions and inhibited by anaerobic conditions [49-51]. Anaerobic conditions during farmyard manure storage cause the degradation of organic material into volatile organic acids, resulting in a decrease in $\mathrm{pH}[52,53]$. Under aerobic litter conditions, the volatile organic acids are degraded to $\mathrm{CO}_{2}$, which increases the $\mathrm{pH}$ with time [54]. From day 14, cake formation occurred in the supply area of the littered control barn. Cake formation is described as compacted litter at a height of 5 to $10 \mathrm{~cm}$ on the surface of the litter [55]. Chadwick [56] demonstrated an $\mathrm{NH}_{3}$ reducing effect of $50-90 \%$ by using compaction and covering cattle manure heaps. The opposite effect is shown during the turning of cattle manure, where the air exchange and the increase in the emitting surface area caused an increase in the $\mathrm{NH}_{3}$ concentration [57]. In the present study, loosening of litter also increased the $\mathrm{NH}_{3}$ concentration, as presented by the post-litter treatment $\mathrm{NH}_{3}$ concentration peak on day 11 of the winter fattening period.

In summary, the animals compacted the litter in the supply area of the littered control barn, resulting in cake formation from day 14. Cake formation led to anaerobic conditions, a decrease in litter $\mathrm{pH}$, and thus an inhibition of the $\mathrm{NH}_{3}$ release. In contrast, animals were separated from their excrements by the elevated perforated floor in the supply area of the experimental barn. As a result, no compaction by the animals took place and aerobic conditions occurred. As mentioned above, aerobic conditions increased the $\mathrm{pH}$ to an alkaline range, which promoted the $\mathrm{NH}_{3}$ release and thus the $\mathrm{NH}_{3}$ concentration and $\mathrm{NH}_{3} \mathrm{ER}$.

Despite the higher $\mathrm{NH}_{3}$ concentrations and $\mathrm{NH}_{3} \mathrm{ER}$, the partially perforated flooring system promotes animal welfare as indicated by animal-based welfare indicators without affecting production performance [12]. Such conflicting goals between animal welfare vs. environmental aspects are already known in livestock husbandry [58]. For example, freerange and organic systems in broiler production are often associated with longer fattening periods in combination with higher feed consumptions and nutrient excretions. These systems promote animal welfare but have a negative impact on the environment $[59,60]$. 
Compared with previous systems, the partially perforated flooring system offers the possibility of implementing reduction measures that were not implementable before. Solution approaches can be used in the supply area, where more than $50 \%$ of the total $\mathrm{NH}_{3}$ generation is expected [43]. For example, underfloor air extraction has become established in pig production to eliminate released $\mathrm{NH}_{3}$ directly at the source $[61,62]$. Such a system could also be tested in combination with the partially perforated flooring system. Almeida et al. [31] mentioned a decrease in $\mathrm{NH}_{3}$ concentration of a totally $(100 \%)$ perforated flooring system in combination with regular manure removal during the fattening period. It is known from aviary systems in laying hens that regular manure removal with manure belts reduces $\mathrm{NH}_{3}$ concentrations $[40,63,64]$. Manure belts underneath the elevated partially perforated area could be tested for regular manure removal in the supply area. The system could also be used for catching animals for slaughter and final manure removal of the whole barn. In addition, the use of acids in pig and cattle slurry has proven to be effective in reducing the $\mathrm{pH}$ and thus the $\mathrm{NH}_{3}$ release $[65,66]$. Similar approaches exist with $\mathrm{pH}$-lowering litter additives in poultry production $[67,68]$. The partially perforated flooring system offers the possibility of testing a system to acidify the material below the elevated perforated area and thus reduce $\mathrm{NH}_{3}$ volatilization. The advantage is that the animals are separated from the acidified material due to the elevated perforated area. With these measures, the increased $\mathrm{NH}_{3}$ volatilization underneath the perforated area could be compensated for and largely avoided. Further research approaches are necessary to reduce the $\mathrm{NH}_{3}$ concentrations inside the barn as well as the resulting $\mathrm{NH}_{3} \mathrm{ER}$, contributing equally to animal welfare and environmental protection.

\section{Conclusions}

This study examined how a partially perforated (50\%) flooring system affects $\mathrm{NH}_{3}$ emissions compared with a littered system in broiler housing. Compared with the littered flooring system, the material underneath the elevated perforated area was not compacted during the fattening periods. Therefore, aerobic conditions were present, which increased the litter $\mathrm{pH}$ and thus the $\mathrm{NH}_{3}$ concentration and $\mathrm{NH}_{3} \mathrm{ER}$ in the final phase of the fattening period. Nevertheless, with the exception of the mechanical litter treatment in the winter fattening period, $\mathrm{NH}_{3}$ concentrations in the exhaust air were below $20 \mathrm{ppm}$ for both floor types. Underfloor air extraction, manure belts, or acidification systems below the elevated perforated area are potential solution approaches to inhibit $\mathrm{NH}_{3}$ release that were not feasible before. Previous studies showed a positive effect of the partially (50\%) perforated flooring system on health- and behavior-based welfare indicators without affecting production performance. In summary, with optimization measures, the partially perforated flooring system could contribute to an improvement in animal welfare and environmental protection at the same time. Further studies should be carried out with a focus on the partially perforated flooring system combined with $\mathrm{NH}_{3}$ reduction strategies from agricultural practice.

Author Contributions: Conceptualization, C.A., A.J.S., M.T., S.H., B.S., I.T., N.K., and W.B.; methodology, C.A., A.J.S., I.T., and W.B.; software, C.A., A.J.S., and I.T.; validation, C.A., A.J.S., and I.T.; formal analysis, C.A., A.J.S., and M.T.; investigation, C.A. and A.J.S.; resources, I.T. and W.B.; data curation, C.A. and S.H.; writing—original draft preparation, C.A.; writing—review and editing, C.A., A.J.S., M.T., I.T., and W.B.; visualization, C.A.; supervision, I.T. and W.B.; project administration, N.K. and W.B.; funding acquisition, B.S., N.K., and W.B. All authors have read and agreed to the published version of the manuscript.

Funding: This research was funded by the Federal Ministry of Food and Agriculture and supported by the Federal Office for Agriculture and Food (2817700214). The authors thank the Verein zur Förderung der Landtechnik Bonn und Haushaltstechnik Bonn e. V. for their contribution to covering publication costs.

Institutional Review Board Statement: The study was carried out at the Educational and Research Center Frankenforst of the Faculty of Agriculture, University of Bonn (Königswinter, Germany; 
$55^{\circ} 42^{\prime} 55 \mathrm{~N}$ and $7^{\circ} 12^{\prime} 26 \mathrm{E}$ ). The experiments were performed in accordance with German regulations and approved by the relevant authority (Landesamt für Natur-, Umwelt- und Verbraucherschutz Nordrhein-Westfalen, Recklinghausen; 81.02.04.2018.A057).

Data Availability Statement: The data presented in this study are available on request from the corresponding author.

Acknowledgments: The authors wish to acknowledge the Educational and Research Center Frankenforst of the Faculty of Agriculture, University of Bonn (Königswinter, Germany) for the care of the animals and their comprehensive support. Also acknowledged are the team of the Institute of Agricultural Engineering, University of Bonn, and many students for their great help in data collection.

Conflicts of Interest: The authors declare no conflict of interest.

\section{References}

1. Bergmann, S.; Schwarzer, A.; Wilutzky, K.; Louton, H.; Bachmeier, J.; Schmidt, P.; Erhard, M.; Rauch, E. Behavior as welfare indicator for the rearing of broilers in an enriched husbandry environment-A field study. J. Vet. Behav. 2017, 19, 90-101. [CrossRef]

2. Kamphues, J.; Youssef, A.; Abd El-Wahab, B.; Üffing, B.; Witte, M.; Tost, M. Influence of feeding and housing on foot pad health in hens and turkeys. Übers. Tierernährg. 2011, 39, 147-195.

3. Youssef, I.M.I.; Beineke, A.; Rohn, K.; Kamphues, J. Experimental study on effects of litter material and its quality on foot pad dermatitis in growing turkeys. Int. J. Poult. Sci. 2010, 9, 1125-1135. [CrossRef]

4. De Jong, I.C.; van Harn, J.; Gunnink, H.; Hindle, V.A.; Lourens, A. Footpad dermatitis in Dutch broiler flocks: Prevalence and factors of influence. Poult. Sci. 2012, 91, 1569-1574. [CrossRef] [PubMed]

5. Haslam, S.M.; Knowles, T.G.; Brown, S.N.; Wilkins, L.J.; Kestin, S.C.; Warriss, P.D.; Nicol, C.J. Factors affecting the prevalence of foot pad dermatitis, hock burn and breast burn in broiler chicken. Br. Poult. Sci. 2007, 48, 264-275. [CrossRef] [PubMed]

6. Martland, M.F. Ulcerative dermatitis dm broiler chickens: The effects of wet litter. Avian Pathol. 1985, 14, 353-364. [CrossRef]

7. Michel, V.; Prampart, E.; Mirabito, L.; Allain, V.; Arnould, C.; Huonnic, D.; Le Bouquin, S.; Albaric, O. Histologically-validated footpad dermatitis scoring system for use in chicken processing plants. Br. Poult. Sci. 2012, 53, 275-281. [CrossRef] [PubMed]

8. Bessei, W. Welfare of broilers: A review. Worlds Poult. Sci. J. 2006, 62, 455-466. [CrossRef]

9. Furtula, V.; Farrell, E.G.; Diarrassouba, F.; Rempel, H.; Pritchard, J.; Diarra, M.S. Veterinary pharmaceuticals and antibiotic resistance of Escherichia coli isolates in poultry litter from commercial farms and controlled feeding trials. Poult. Sci. 2010, 89, 180-188. [CrossRef] [PubMed]

10. Kemper, N. Veterinary antibiotics and their possible impact on resistant bacteria in the environment. In Antibiotic Resistance: Causes and Risk Factors, Mechanisms and Alternatives, 2nd ed.; Bonilla, A.R., Muniz, K.P., Eds.; Nova Science Publishers, Inc.: New York, NY, USA, 2009; pp. 467-495. ISBN 9781607419730.

11. Amador, P.; Fernandes, R.; Prudêncio, C.; Duarte, I. Prevalence of antibiotic resistance genes in multidrug-resistant enterobacteriaceae on portuguese livestock manure. Antibiotics 2019, 8, 23. [CrossRef] [PubMed]

12. Adler, C.; Tiemann, I.; Hillemacher, S.; Schmithausen, A.J.; Müller, U.; Heitmann, S.; Spindler, B.; Kemper, N.; Büscher, W. Effects of a partially perforated flooring system on animal-based welfare indicators in broiler housing. Poult. Sci. 2020, 99, 3343-3354. [CrossRef]

13. Heitmann, S.; Stracke, J.; Adler, C.; Ahmed, M.F.E.; Schulz, J.; Büscher, W.; Kemper, N.; Spindler, B. Effects of a slatted floor on bacteria and physical parameters in litter in broiler houses. Vet. Anim. Sci. 2020, 9, 100115. [CrossRef] [PubMed]

14. Wood, D.J.; van Heyst, B.J. A review of ammonia and particulate matter control strategies for poultry housing. Trans. ASAE 2016, 59, 329-344. [CrossRef]

15. Schrader, L.; Müller, B. Night-time roosting in the domestic fowl: The height matters. Appl. Anim. Behav. Sci. 2009, 121, 179-183. [CrossRef]

16. Larsen, B.; Vestergaard, K.S.; Hogan, J.A. Development of dustbathing behavior sequences in the domestic fowl: The significance of functional experience. Dev. Psychobiol. 2000, 37, 5-12. [CrossRef]

17. Blokhuis, H.J. The effect of a sudden change in floor type on pecking behaviour in chicks. Appl. Anim. Behav. Sci. 1989, 22, 65-73. [CrossRef]

18. Tahamtani, F.M.; Pedersen, I.J.; Toinon, C.; Riber, A.B. Effects of environmental complexity on fearfulness and learning ability in fast growing broiler chickens. Appl. Anim. Behav. Sci. 2018, 207, 49-56. [CrossRef]

19. Baxter, M.; Bailie, C.L.; O'Connell, N.E. Play behaviour, fear responses and activity levels in commercial broiler chickens provided with preferred environmental enrichments. Animal 2019, 13, 171-179. [CrossRef]

20. De Jonge, J.; van Trijp, H.C.M. Meeting heterogeneity in consumer demand for animal welfare: A reflection on existing knowledge and implications for the meat sector. J. Agric. Environ. Ethics 2013, 26, 629-661. [CrossRef]

21. Almuhanna, E.A.; Ahmed, A.S.; Al-Yousif, Y.M. Effect of air contaminants on poultry immunological and production performance. Int. J. Poult. Sci. 2011, 10, 461-470. [CrossRef] 
22. Valentine, H. A study of the effect of different ventilation rates on the ammonia concentrations in the atmosphere of broiler houses. Br. Poult. Sci. 1964, 5, 149-159. [CrossRef]

23. Ihrig, A.; Hoffmann, J.; Triebig, G. Examination of the influence of personal traits and habituation on the reporting of complaints at experimental exposure to ammonia. Int. Arch. Occup. Environ. Health 2006, 79, 332-338. [CrossRef] [PubMed]

24. Wu, Y.N.; Yan, F.F.; Hu, J.Y.; Chen, H.; Tucker, C.M.; Green, A.R.; Cheng, H.W. The effect of chronic ammonia exposure on acute-phase proteins, immunoglobulin, and cytokines in laying hens. Poult. Sci. 2017, 96, 1524-1530. [CrossRef] [PubMed]

25. Miles, D.M.; Branton, S.L.; Lott, B.D. Atmospheric ammonia is detrimental to the performance of modern commercial broilers. Poult. Sci. 2004, 83, 1650-1654. [CrossRef] [PubMed]

26. Wang, Y.M.; Meng, Q.P.; Guo, Y.Z.; Wang, Y.Z.; Wang, Z.; Yao, Z.L.; Shan, T.Z. Effect of atmospheric ammonia on growth performance and immunological response of broiler chickens. J. Anim. Vet. Adv. 2010, 22, 2802-2806. [CrossRef]

27. Xin, H.; Gates, R.S.; Green, A.R.; Mitloehner, F.M.; Moore, P.A.; Wathes, C.M. Environmental impacts and sustainability of egg production systems. Poult. Sci. 2011, 90, 263-277. [CrossRef]

28. Li, H.; Lin, C.; Collier, S.; Brown, W.; White-Hansen, S. Assessment of frequent litter amendment application on ammonia emission from broilers operations. J. Air Waste Manag. Assoc. 2013, 63, 442-452. [CrossRef] [PubMed]

29. Van Breemen, N.; van Dijk, H.F.G. Ecosystem effects of atmospheric deposition of nitrogen in The Netherlands. Environ. Pollut. 1988, 54, 249-274. [CrossRef]

30. Boggia, A.; Paolotti, L.; Antegiovanni, P.; Fagioli, F.F.; Rocchi, L. Managing ammonia emissions using no-litter flooring system for broilers: Environmental and economic analysis. Environ. Sci. Policy 2019, 101, 331-340. [CrossRef]

31. Almeida, E.A.; Arantes de Souza, L.F.; Sant'Anna, A.C.; Bahiense, R.N.; Macari, M.; Furlan, R.L. Poultry rearing on perforated plastic floors and the effect on air quality, growth performance, and carcass injuries-Experiment 1: Thermal comfort. Poult. Sci. 2017, 96, 3155-3162. [CrossRef]

32. Li, H.; Wen, X.; Alphin, R.; Zhu, Z.; Zhou, Z. Effects of two different broiler flooring systems on production performances, welfare, and environment under commercial production conditions. Poult. Sci. 2017, 96, 1108-1119. [CrossRef]

33. Schmithausen, A.J.; Trimborn, M.; Büscher, W. Methodological comparison between a novel automatic sampling system for gas chromatography versus photoacoustic spectroscopy for measuring greenhouse gas emissions under field conditions. Sensors 2016, 16, 1638. [CrossRef]

34. Schmithausen, A.J.; Schiefler, I.; Trimborn, M.; Gerlach, K.; Südekum, K.-H.; Pries, M.; Büscher, W. Quantification of methane and ammonia emissions in a naturally ventilated barn by using defined criteria to calculate emission rates. Animals $2018,8,75$. [CrossRef]

35. Welfare Quality. Welfare Quality®Assessment Protocol for Poultry (Broilers, Laying Hens); Welfare Quality®Consortium: Lelystad, The Netheralands, 2009.

36. Akpobome, G.O.; Fanguy, R.C. Evaluation of cage floor systems for production of commercial broilers. Poult. Sci. 1992, 71, 274-280. [CrossRef]

37. Cengiz, Ö.; Hess, J.B.; Bilgili, S.F. Effect of protein source on the development of footpad dermatitis in broiler chickens reared on different flooring types. Arch. Geflügelk. 2013, 77, 166-170.

38. Çavuşoğlu, E.; Petek, M.; Abdourhamane, İ.M.; Akkoc, A.; Topal, E. Effects of different floor housing systems on the welfare of fast-growing broilers with an extended fattening period. Arch. Anim. Breed. 2018, 61, 9-16. [CrossRef]

39. Çavuşoğlu, E.; Petek, M. Effects of different floor materials on the welfare and behaviour of slow- and fast-growing broilers. Arch. Anim. Breed. 2019, 62, 335-344. [CrossRef]

40. Groot Koerkamp, P.W.G. Review on emissions of ammonia from housing systems for laying hens in relation to sources, processes, building design and manure handling. J. Agric. Eng. Res. 1994, 59, 73-87. [CrossRef]

41. Meda, B.; Hassouna, M.; Aubert, C.; Robin, P.; Dourmad, J.Y. Influence of rearing conditions and manure management practices on ammonia and greenhouse gas emissions from poultry houses. Worlds Poult. Sci. J. 2011, 67, 441-456. [CrossRef]

42. Ivoš, J.; Asaj, A.; Marjanović, L.; Madžirov, Ž. A contribution to the hygiene of deep litter in the chicken house. Poult. Sci. 1966, 45, 676-683. [CrossRef]

43. Miles, D.M.; Brooks, J.P.; McLaughlin, M.R.; Rowe, D.E. Broiler litter ammonia emissions near sidewalls, feeders, and waterers. Poult. Sci. 2013, 92, 1693-1698. [CrossRef] [PubMed]

44. Reece, F.N.; Bates, B.J.; Lott, B.D. Ammonia control in broiler houses. Poult. Sci. 1979, 58, 754-755. [CrossRef]

45. Xue, S.K.; Chen, S.; Hermanson, R.E. Measuring ammonia and hydrogen sulfide emitted from manure storage facilities. Trans ASAE 1998, 41, 1125-1130. [CrossRef]

46. Li, H.; Xin, H.; Burns, R.T.; Roberts, S.A.; Li, S.; Kliebenstein, J.; Bregendahl, K. Reducing ammonia emissions from laying-hen houses through dietary manipulation. J. Air Waste Manag. Assoc. 2012, 62, 160-169. [CrossRef] [PubMed]

47. Hartung, J.; Phillips, V.R. Control of gaseous emissions from livestock buildings and manure stores. J. Agric. Eng. Res. 1994, 57, 173-189. [CrossRef]

48. Kirchmann, H.; Lundvall, A. Treatment of solid animal manures: Identification of low $\mathrm{NH}_{3}$ emission practices. Nutr. Cycl. Agroecosyst. 1998, 51, 65-71. [CrossRef]

49. Kirchmann, H.; Witter, E. Ammonia volatilization during aerobic and anaerobic manure decomposition. Plant Soil 1989, 115, 35-41. [CrossRef] 
50. Mahimairaja, S.; Bolan, N.S.; Hedley, M.J.; Macgregor, A.N. Losses and transformation of nitrogen during composting of poultry manure with different amendments: An incubation experiment. Bioresour. Technol. 1994, 47, 265-273. [CrossRef]

51. Amon, B.; Amon, T.; Boxberger, J.; Alt, C. Emissions of NH3, N2O and CH4 from dairy cows housed in a farmyard manure tying stall (housing, manure storage, manure spreading). Nutr. Cycl. Agroecosyst. 2001, 60, 103-113. [CrossRef]

52. Acharya, C.N. Studies on the anaerobic decomposition of plant materials. Biochem. J. 1935, 29, 1116-1120. [CrossRef]

53. Sommer, S.G.; Husted, S. The chemical buffer system in raw and digested animal slurry. J. Agric. Sci. 1995, 124, 45-53. [CrossRef]

54. Christensen, M.L.; Sommer, S.G. Manure characterization and inorganic chemistry. In Animal Manure Recycling: Treatment and Management, 1st ed.; Sommer, S.G., Christensen, M.L., Schmidt, T., Jensen, L., Eds.; John Wiley \& Sons, Ltd.: Hoboken, NJ, USA, 2013; pp. 41-65.

55. Sistani, K.R.; Brink, G.E.; McGowen, S.L.; Rowe, D.E.; Oldham, J.L. Characterization of broiler cake and broiler litter, the by-products of two management practices. Bioresour. Technol. 2003, 90, 27-32. [CrossRef]

56. Chadwick, D.R. Emissions of ammonia, nitrous oxide and methane from cattle manure heaps: Effect of compaction and covering. Atmos. Environ. 2005, 39, 787-799. [CrossRef]

57. Parkinson, R. Effect of turning regime and seasonal weather conditions on nitrogen and phosphorus losses during aerobic composting of cattle manure. Bioresour. Technol. 2004, 91, 171-178. [CrossRef]

58. Siegford, J.M.; Powers, W.; Grimes-Casey, H.G. Environmental aspects of ethical animal production. Poult. Sci. 2008, 87, 380-386. [CrossRef]

59. Leinonen, I.; Williams, A.G.; Wiseman, J.; Guy, J.; Kyriazakis, I. Predicting the environmental impacts of chicken systems in the United Kingdom through a life cycle assessment: Broiler production systems. Poult. Sci. 2012, 91, 8-25. [CrossRef] [PubMed]

60. Schwean-Lardner, K.; Herwig, E. Poultry Welfare: Future Directions and Challenges? Meat Muscle Biol. 2020, 4, 1-5. [CrossRef]

61. Nicks, B. Ammonia reduction in pigs. In Livestock Production and Society; Geers, R., Madec, F., Eds.; Wageningen Academic Publishers: Wageningen, The Netherlands, 2006; pp. 179-190. ISBN 9789076998893.

62. Lagadec, S.; Landrain, B.; Landrain, P.; Robin, P.; Hassouna, M. Ammonia and greenhouse gas emissions in pig fattening on slatted floor with excrementdischarge by flat scraping. In Emissions of Gas and Dust from Livestock; IFIP-Institut du Porc: Paris, France, 2013.

63. Nicholson, F.A.; Chambers, B.J.; Walker, A.W. Ammonia emissions from broiler litter and laying hen manure management systems. Biosyst. Eng. 2004, 89, 175-185. [CrossRef]

64. Fournel, S.; Pelletier, F.; Godbout, S.; Lagacé, R.; Feddes, J. Odour emissions, hedonic tones and ammonia emissions from three cage layer housing systems. Biosyst. Eng. 2012, 112, 181-191. [CrossRef]

65. Fangueiro, D.; Hjorth, M.; Gioelli, F. Acidification of animal slurry-A review. J. Environ. Manag. 2015, 149, 46-56. [CrossRef] [PubMed]

66. Misselbrook, T.; Hunt, J.; Perazzolo, F.; Provolo, G. Greenhouse gas and ammonia emissions from slurry storage: Impacts of temperature and potential mitigation through covering (pig slurry) or acidification (cattle slurry). J. Environ. Qual. 2016, 45, 1520-1530. [CrossRef] [PubMed]

67. Nahm, K.H. Environmental effects of chemical additives used in poultry litter and swine manure. Crit. Rev. Environ. Sci. Technol. 2005, 35, 487-513. [CrossRef]

68. Cockerill, S.A.; Gerber, P.F.; Walkden-Brown, S.W.; Dunlop, M.W. Suitability of litter amendments for the Australian chicken meat industry. Anim. Prod. Sci. 2020, 60, 1469. [CrossRef] 